November 2003 - NREL/CP-500-34692

\title{
Hybrid Power System with a Controlled Energy Storage
}

\section{Preprint}

E. Muljadi and J. T. Bialasiewicz

To be presented at the $29^{\text {th }}$ Annual Conference of the IEEE Industrial Electronics Society Roanoke, Virginia

November 2-6, 2003

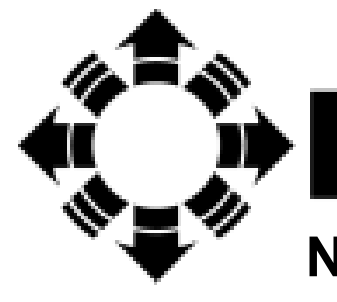

National Renewable Energy Laboratory

1617 Cole Boulevard

Golden, Colorado 80401-3393

NREL is a U.S. Department of Energy Laboratory

Operated by Midwest Research Institute $\bullet$ Battelle $\bullet$ Bechtel

Contract No. DE-AC36-99-G010337 


\section{NOTICE}

The submitted manuscript has been offered by an employee of the Midwest Research Institute (MRI), a contractor of the US Government under Contract No. DE-AC36-99G010337. Accordingly, the US Government and MRI retain a nonexclusive royalty-free license to publish or reproduce the published form of this contribution, or allow others to do so, for US Government purposes.

This report was prepared as an account of work sponsored by an agency of the United States government. Neither the United States government nor any agency thereof, nor any of their employees, makes any warranty, express or implied, or assumes any legal liability or responsibility for the accuracy, completeness, or usefulness of any information, apparatus, product, or process disclosed, or represents that its use would not infringe privately owned rights. Reference herein to any specific commercial product, process, or service by trade name, trademark, manufacturer, or otherwise does not necessarily constitute or imply its endorsement, recommendation, or favoring by the United States government or any agency thereof. The views and opinions of authors expressed herein do not necessarily state or reflect those of the United States government or any agency thereof.

Available electronically at http://www.osti.gov/bridge

Available for a processing fee to U.S. Department of Energy and its contractors, in paper, from:

U.S. Department of Energy

Office of Scientific and Technical Information

P.O. Box 62

Oak Ridge, TN 37831-0062

phone: 865.576.8401

fax: 865.576.5728

email: reports@adonis.osti.gov

Available for sale to the public, in paper, from:

U.S. Department of Commerce

National Technical Information Service

5285 Port Royal Road

Springfield, VA 22161

phone: 800.553 .6847

fax: 703.605.6900

email: orders@ntis.fedworld.gov

online ordering: http://www.ntis.gov/ordering.htm

Printed on paper containing at least $50 \%$ wastepaper, including $20 \%$ postconsumer waste 


\title{
Hybrid Power System with
}

\section{a Controlled Energy Storage}

\author{
Eduard Muljadi, Senior Member, IEEE, Jan T. Bialasiewicz, Senior Member, IEEE
}

\begin{abstract}
We investigated a small isolated hybrid power system that used two types of power generation; wind turbine and diesel generation. The interaction of diesel generation, the wind turbine, and the local load is complicated because both the load and the wind turbine fluctuate during the day. These fluctuations create imbalances in power distribution (energy sources are not equal to energy sinks) that can affect the frequency and the voltage in the power system. The addition of energy storage will help balance the distribution of power in the power network.
\end{abstract}

For this paper, we studied the interaction among hybrid power system components and the relative size of the components. We also show how the contribution of wind energy affects the entire power system and distribution and the role of energy storage under the transient conditions caused by load changes and wind turbine start ups.

Index Terms - wind turbine, diesel generator, hybrid power system, renewable energy, energy storage.

\section{INTRODUCTION}

$\mathrm{S}_{\mathrm{i}}^{\mathrm{n}}$ INCE ancient times, wind energy has been used to improve humankind's quality of life. Windmills were used to pump water and mill grain, along with many other uses [1, 2, 3, 4].

Today, wind turbines are used for similar purposes (i.e., water or oil pumping, battery charging, and utility generation). One important aspect of wind turbine applications, especially in an industrial environment, is that wind turbines generate electricity without creating pollution.

Wind turbines are also well suited for generating electricity in isolated places with no connections to the utility grid $[2,3,4]$. However, in isolated applications, especially very small applications, the power system components (sources and loads) are limited, and the system networks are weak in many cases. Thus, any changes in the power input or output of one component may affect the rest of the system

E. Muljadi is with the National Wind Technology Center, National Renewable Energy Laboratory, 1617 Cole Boulevard, Golden, CO, USA (e-mail: eduard muljadi@,nrel.gov ).

J.T. Bialasiewicz is with the Department of Electrical Engineering, University of Colorado at Denver, Campus Box 110, P.O. Box 173364, Denver, CO 80217-3364, USA (phone: 303-556-4333; e-mail: jan.bialasiewicz@cudenver.edu ). more dramatically than in a larger system where the smoothing effect of many components benefits the overall system.

In this paper, we analyze a hybrid power system consisting of a wind turbine, a diesel generator, a local load, and energy storage. We also present the impact of energy storage on the power system performance. The results and conclusions of this analysis apply to similar hybrid power systems.

\section{SYSTEM CONFIGURATION}

The system has two types of generation: the diesel generator and the wind turbine generator (Figure 1). The energy storage can act as a load or as a generator depending on the need. The diesel generator provides smooth output power, whereas the output power of a wind turbine depends on the wind velocity. As the wind velocity varies, so does is the power generation. For example, if the wind speed changes very smoothly, the output power of the wind turbine will also change very smoothly. On the other hand, wind turbulence causes the output power to fluctuate. Figure 1 is a single line diagram that represents the analyzed power system.

The wind turbine has an induction generator with a capacity ranging from $40 \mathrm{~kW}$ to $225 \mathrm{~kW}$. At low wind speeds, the generator operates at $900 \mathrm{rpm}$ with a rated capacity of $40 \mathrm{~kW}$. At high wind speeds, the generator speed is $1,200 \mathrm{rpm}$ with a rated capacity of $225 \mathrm{~kW}$. We used 150 $\mathrm{kW}$ of energy storage as a buffer to operate as a load or a source depending on the need. This paper discusses only fixed-speed wind turbine generation and does not cover variable-speed wind turbine generation [5].

The diesel engine, which has a rated capacity of $400 \mathrm{~kW}$, is operated in parallel with the wind turbine to supply the load. The local loads are mostly residential and light loads. Other loads include water pumps, compressors, and heavy equipment. An $80-\mathrm{kW}$ water pump represents the transient condition of a heavy load.

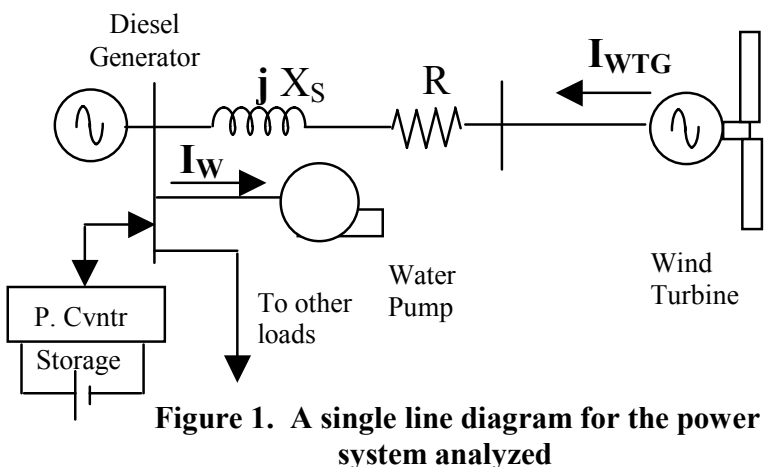




\section{COMPONENTS OF POWER SYSTEM}

The system we discuss in this paper consists of four major subsystems: a diesel generator, a wind turbine generator, heavy (industrial) loads, and energy storage. In the power system network, the balance of active power and reactive power must be maintained. The diesel genset, then, must be able to keep the power balanced when the wind turbine or local load varies. This task is easy to accomplish provided the diesel genset is sufficiently sized. Although they are important, we will not cover the details of the dynamic model for electric machines used in the simulation. Many good textbooks are available on this subject.

\section{A.Diesel Generator}

In terms of an electrical system, a diesel generator can be represented as a prime mover and a generator. Ideally, the prime mover is capable of supplying any power demand up to rated power at constant frequency, and the synchronous generator connected to it must be able to keep the voltage constant at any load condition.

Figure 2 is a block diagram of the diesel generator. The diesel engine keeps the frequency constant by maintaining the rotor speed constant via its governor.

The synchronous generator must control its output voltage by controlling the excitation current. Thus, as a unit, the diesel generating system must be able to control its frequency and its output voltage. The inertia of the diesel genset, the sensitivity of the governor, and the power capability of the diesel engine all affect the diesel generator's ability to respond to frequency changes. The ability of the synchronous generator to control its voltage is affected by the field winding time constant, the availability of the direct current (DC) power to supply the field winding, and the response of the voltage control regulation mechanism.

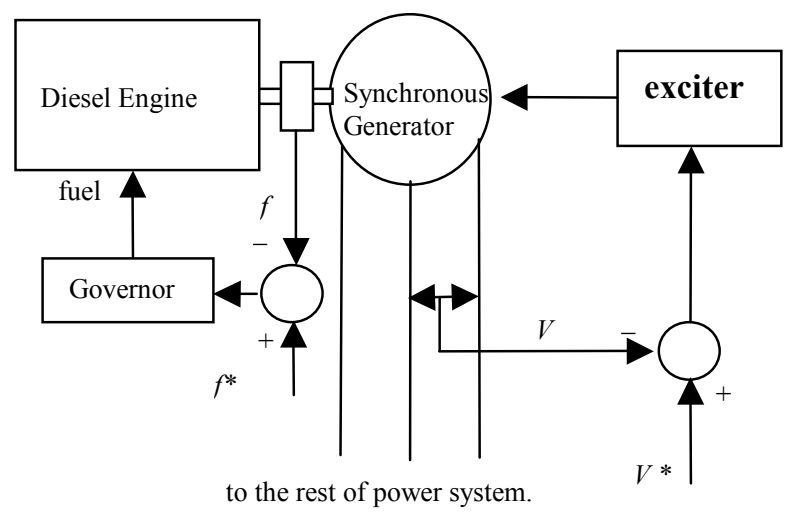

Figure 2. Diesel generator control block diagram

\section{B. Wind Turbine}

The main components of a wind turbine are the rotor of the turbine, which is the prime mover, and an induction generator. In general, the rotor is connected to the generator via a gearbox that matches the rotational speed. The simplest system uses a fixed-speed turbine. A fixed-speed turbine must rely on the blade-stall condition to limit the output power when the winds are at high speed. Note that, although the rotor speed of an induction generator varies with wind speed, the speed range is within a $1 \%$ to $2 \%$ slip. On the other hand, the wind speed variation may range from $5 \mathrm{~m} / \mathrm{s}$ to $25 \mathrm{~m} / \mathrm{s}$; thus, in terms of the wind turbine, the induction generator operates at a relatively "fixed speed" compared to the range of wind speed variation.

\section{Induction Machines}

Most electric machines used in industry as prime movers are induction motors. Two applications of induction machines in the power system network fall within the scope of this study: one as the generator on a wind turbine and the other as a motor driving large pumps and compressors. By its nature, an induction machine is an inductive load. This machine absorbs reactive power either as a motor or generator. The reactive power absorbed by the induction machine comes from the line to which it is connected. In a hybrid power system, the reactive power comes from the synchronous generator of the diesel genset. In a wind turbine generator, a fixed capacitor is usually installed to supply some of the reactive power that the induction generator needs. Figure 3 shows the equivalent circuit of an induction machine connected to a power system. The power system is represented by infinite bus $\mathrm{E}_{\mathrm{s}}$ and the line impedance is represented by reactance $X_{s}$.

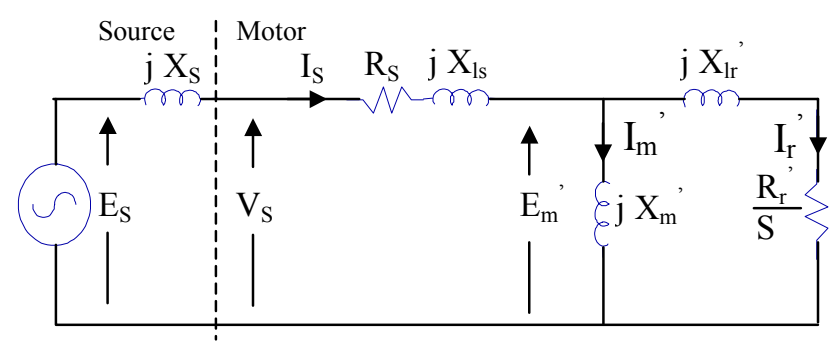

Figure 3. Equivalent circuit of an induction machine connected to power system

\section{Various Loads}

In the power system considered, there are two major loads. The first is a large water pump representing a typical industrial load. The second is a collection of loads for which the size and power factor can be programmed throughout the day to represent a typical village load. The voltage at the terminal of the load varies as a result of a voltage drop across the line impedance. The voltage drop across the line impedance varies depending on the size of the current and the power factor of the load.

The terminal voltage for a wind turbine generator $\left(V_{S}\right)$, as the output current of induction machine, varies from start-up to generating mode. During start-up, voltage drops significantly at the terminal voltage of the induction machine. The voltage drop across line impedance is caused by the current surge during start-up. In addition, the phase angle of the stator current is very large and lagging. The combination of a poor power factor and a lagging, large current surge creates a voltage dip at the terminal of the induction machine during start-up. Thus, a start-up of short duration is preferable to a prolonged one. 


\section{E. Energy Storage}

The energy storage can be of different types (i.e. flywheel, battery, hydrogen/fuel-cell, hydropower etc.). In this paper, we assumed energy storage with a power converter interface to the power network. The power converter is connected to the energy storage at one end. With variability of wind resource, energy storage is an excellent contributor to the power system. The energy storage behaves like a large buffer to accommodate the unequal instantaneous energy in the power system. Ideally, at any instant of time, there should be a zero net exchange between the energy sources and the energy sinks (both real and reactive power). If this balance is not achieved, the voltage and frequency of the system changes to maintain equilibrium. At any instant, the energy storage behaves either as an energy source or energy sink depending of the mode of operation.

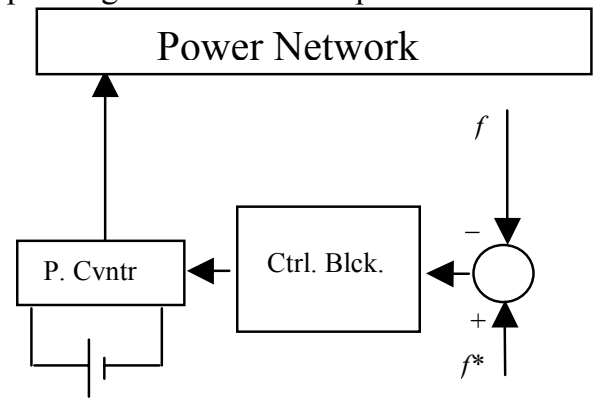

Figure 4. Energy Storage control block diagram

It is assumed that the energy storage has a power converter interfacing the power network. Although it is possible for the power converter to function as a reactive power compensator, the cost of a power converter is very expensive compared to other means of reactive power compensation currently available in the market. Keep in mind that the size of the power semiconductor in the power converter is limited by its current limit and its voltage limit. Thus, minimizing the current passing through the power switches will minimize the current rating of the power converter and will lower the cost. For this paper, we only used the power converter to process real power in and out of the energy storage. Figure 4 shows a block diagram of energy storage control algorithm. It uses frequency deviation to indicate a real power imbalance in the system. The frequency deviation is also used as the feedback to control the energy storage output. If the load power demand is higher than the power supply available, the frequency of the diesel generator will slowly drop. Other energy stored in the system includes the kinetic energy in the turbine blades, the diesel generator inertia, and energy in the inductors and capacitors, etc.

\section{F. Balance of Energy in the System}

In the isolated system we studied, the balance of real and reactive power must always be maintained. The balance of real power is maintained by the governor of the diesel generator. The balance of reactive power is maintained by the exciter of the diesel's synchronous generator. When the load demands more power than the diesel and the wind turbine can produce, and the diesel engine has reached its highest limit, as the loads continue to increase, the governor of the diesel cannot push more power, and the rotor speed of the diesel will start to drop. The frequency of the generator will then drop until balance is reached or the system collapses.

The voltage in the system is also an indicator of the balance in the system. When the reactive power demand from the loads is higher than what can be provided by the diesel generator, the capacitor, and other means of compensation, the system voltage will drop.

Although the size of output and input of the energy storage is adjustable, it is limited by its ratings. For this paper, we assumed that the energy storage is capable of storing and providing long-term energy to the power network to maintain system balance. In reality, only a limited amount of energy can be stored. We will not discuss energy analysis in detail in this paper. In practice, the energy will be stored when the wind turbine produces enough power and the diesel is operating under light load. The actual loads are divided into critical and non-critical loads. Critical loads are supplied at all times and non-critical loads are served only if there is enough source and it will be shed off the system when the voltage or frequency drops below the allowable limit. With the existence of sufficiently sized energy storage, it is possible to serve all the loads (critical and non-critical) all the time.

\section{DYNAMIC ANALYSIS}

In this section, we simulated the power system using a package program developed at the National Renewable Energy Laboratory [NREL; 4]. The case studies look at different aspects of major power system components in the power network. The first case study investigates the diesel power component. In the power network, a diesel generator must maintain system balance by responding properly to power changes.

\section{A. Case Study I: Diesel-Wind Turbine Interaction}

A diesel generator consists of a diesel engine and a synchronous generator. The diesel engine is responsible for controlling the frequency and keeping it constant through its governor. The synchronous generator is responsible for controlling the voltage via its field winding and voltage controller.

Undersized diesel engine: The ability of a diesel engine to change speed is its accelerating or decelerating power. The diesel accelerates when the input power is higher than the electrical output power of the generator (including losses). The diesel decelerates when the input power is lower than the electrical output power of the generator (including losses). An oversized diesel engine does not have problems accelerating or decelerating, but an undersized diesel engine may create problems, during, for example, the start-up of a wind turbine or large compressor.

Figure 5 illustrates a condition where the diesel is undersized with respect to the load. The genset frequency and the terminal voltage of the wind turbine generator are shown on the top graph, and the real power of the diesel, wind turbine, water pump, and local load are shown on the bottom graph. At start-up, the wind turbine uses the smaller, 


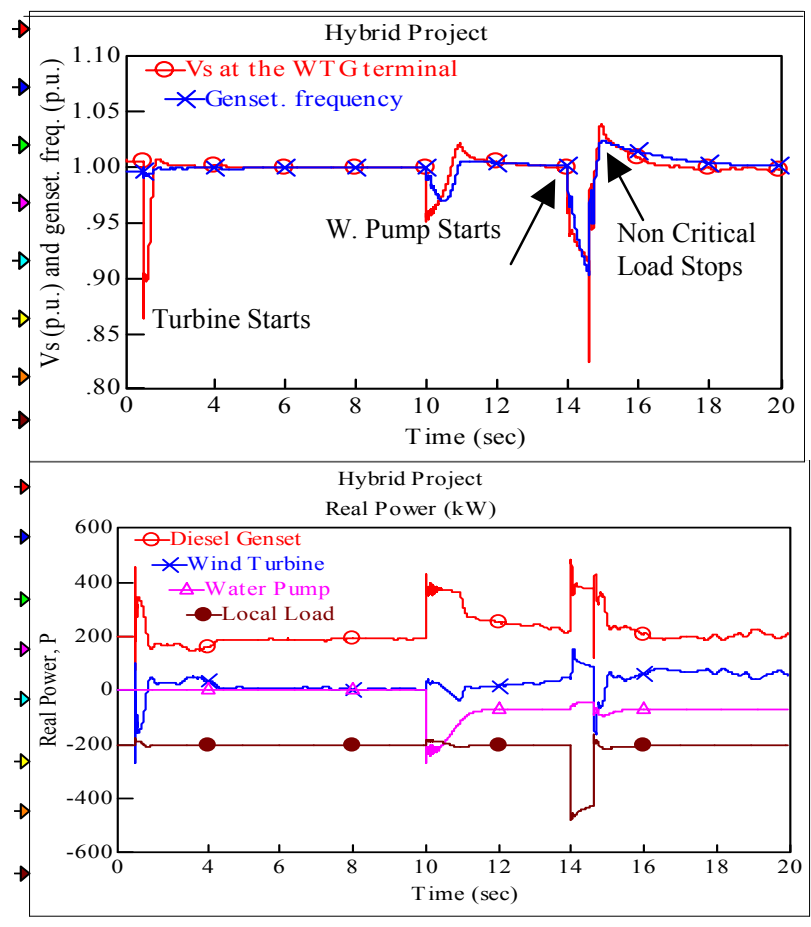

Figure 5. Voltage, frequency, and power to illustrate an undersized diesel genset

$40-\mathrm{kW}$ generator to motor up and bring the induction machine up to speed. Because the wind speed is low, the wind turbine operates at low output power, and the local load is set to $200 \mathrm{~kW}$. The diesel engine has a rated power of 400 $\mathrm{kW}$. At $\mathrm{t}=2 \mathrm{~s}$, the wind turbine is turned on. As we can see, the voltage dip and the frequency dip are not very large, because the wind turbine is started using a smaller generator.

At $\mathrm{t}=10 \mathrm{~s}$, the $80-\mathrm{kW}$ water pump is started up. The startup time for the water pump is longer than that of the wind turbine because the wind turbine is started when the rotor speed is close to the synchronous speed and the wind turbine also gets some help from the wind. The voltage drop is not very significant, but the frequency of the diesel drops about $3 \%$. The diesel output power increases to cover the real power needed, whereas the contribution from the wind turbine is insignificant because the wind is low. For a short time, the induction generator enters the motoring range between $\mathrm{t}=10.8 \mathrm{~s}$ and $\mathrm{t}=11.3 \mathrm{~s}$. After the condition is restored, at $\mathrm{t}=14 \mathrm{~s}$, the additional local load $(300 \mathrm{~kW}$ noncritical) is turned on, bringing the total load to $580 \mathrm{~kW}$.

Because the diesel can carry only up to $400 \mathrm{~kW}$ and the wind's contribution is very small at about $40 \mathrm{~kW}$, the voltage and frequency start decreasing, and the voltage and frequency sensors detect the change. If the frequency drops below $95 \%$ and the voltage drops below $90 \%$ for an elapsed time of $0.5 \mathrm{~s}$, the controller will drop the additional load (300 $\mathrm{kW})$ and keep the critical load $(200 \mathrm{~kW})$ to regain the voltage and frequency. After the load is shed at $t=14.5 \mathrm{~s}$, the frequency and voltage eventually return to normal. When the frequency drops, the wind turbine's power contribution suddenly jumps because of a sudden increase of generating slip. Eventually, the genset frequency increases again for a short period and the induction generator enters into the motoring condition (between $\mathrm{t}=14.5 \mathrm{~s}$ and $\mathrm{t}=15 \mathrm{~s}$ ). This condition worsens if the mechanical time constant of the wind turbine rotor (including the blade) is higher than the diesel genset time constant. In other words, the changing of the genset rotor speed is much faster than the changing of the wind turbine rotor speed. The response to the load change is shown by how fast the governor corrects the frequency and how fast the generator's field excitation control reacts to the voltage changes.

Undersized diesel engine with energy storage:

As shown in the previous subsection, an undersized diesel engine cannot supply all energy needed, and it must shed some of the non-critical load to retain power-system stability. To remedy this situation, a $150-\mathrm{kW}$ energy storage is installed to bring the combined output of the diesel genset and energy storage up to $550 \mathrm{~kW}$. Figure 6 shows the improved power system after the energy storage is added. The same simulation is performed except it is now equipped with an energy storage.

There is a significant improvement in the frequency regulation after the storage is installed to stabilize the system. The non-critical load $(300 \mathrm{~kW})$ survives even during lowwind conditions. The frequency dips during the wind turbine start-up and the water pump start-up, and when the $300 \mathrm{~kW}$ load non-critical load is switched, it is reduced dramatically. Obviously, the capability of the energy storage to deliver a large amount of power instantaneously plays a major role in restoring the frequency of the power system. An additional benefit is noticed in the system voltage behavior of the wind turbine. Because the change in the frequency deviation presented to the wind turbine induction generator is small and smooth, the behavior of the stator current at the induction generator is also smooth. Thus it reduces the Ldi/dt and overall voltage drop across the line.

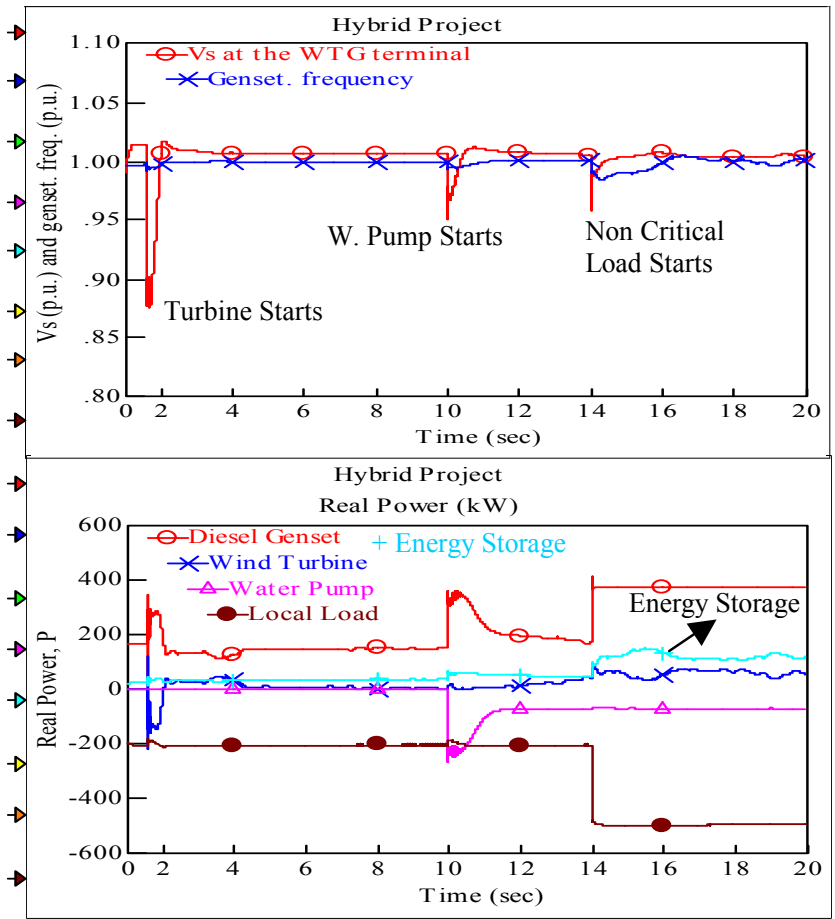

Figure 6. Voltage, frequency, and power to illustrate an undersized diesel genset with storage 
Oversized wind turbine:

When the wind power output exceeds the power required by the load, the synchronous generator of the diesel genset becomes a synchronous motor that tends to accelerate the rotor speed of the diesel engine. The excess energy from the wind power, then, tries to drive the diesel engine. Because the diesel engine has only a small braking capability resulting from engine compression, the frequency control can be lost when the extra power generated by the wind turbine is sufficiently high.

In Figure 7, the diesel generator has a rated power of 400 $\mathrm{kW}$, the local load is initially set to $280 \mathrm{~kW}$ and at $\mathrm{t}=4 \mathrm{~s}$, and the local load is set to $100 \mathrm{~kW}$. When the diesel is started, there is only a local load of $280 \mathrm{~kW}$. The wind turbine is then started at $\mathrm{t}=2 \mathrm{~s}$ with a $225-\mathrm{kW}$ induction machine. Although the diesel genset is rated at only $400 \mathrm{~kW}$ and the wind turbine is started with a $225-\mathrm{kW}$ induction machine, the effect of wind turbine start-up on the power system is very mild, mostly because the induction machine current is limited by a soft start. A soft start is a device that limits starting current during start-up. It consists of a pair of back-to-back thyristors installed in series with each phase of the motor winding. Because the firing angle of the thyristor can be controlled, the size of the starting current can be adjusted by controlling the firing angle of the thyristors. As we can see (Figure 5), the same wind turbine $(225 \mathrm{~kW})$ draws a starting power of $300 \mathrm{~kW}$, but after the soft start is installed (Figure 7), the power surge during start-up drops to about $100 \mathrm{~kW}$.

After the wind turbine enters generating mode (at about $\mathrm{t}=$ $2.5 \mathrm{~s})$, the local load $(280 \mathrm{~kW})$ is shared between the diesel genset $(55 \mathrm{~kW})$ and the wind turbine $(225 \mathrm{~kW})$. The voltage and frequency are maintained constant, and the diesel genset

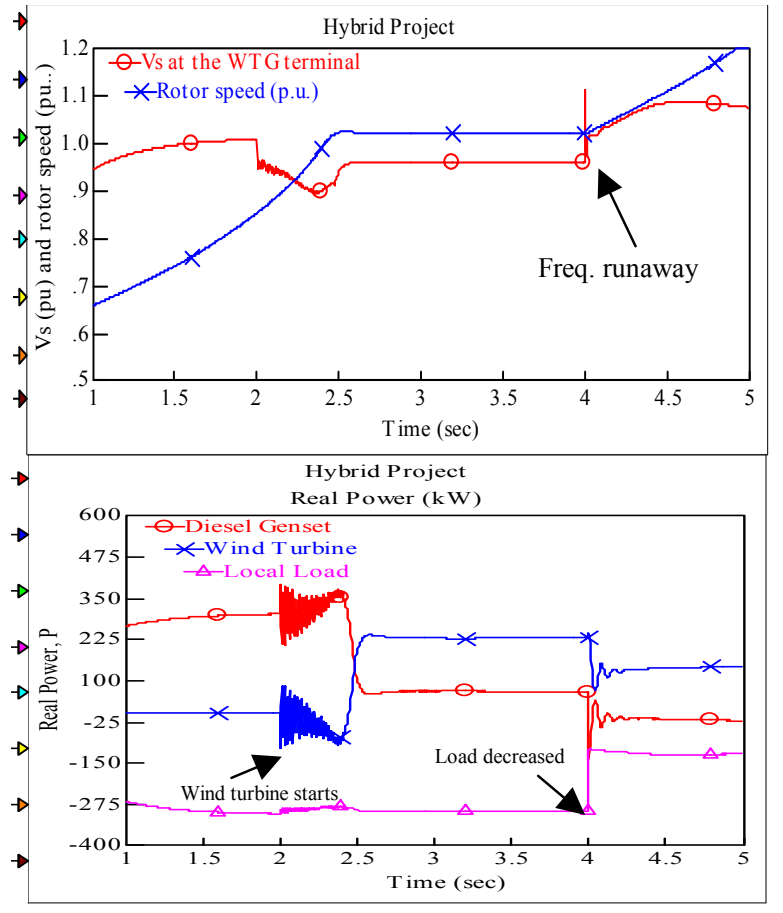

Figure 7. Voltage, rotor speed, and power of an oversize wind turbine generates only a small percentage of its rated load (about $13 \%$ ). This makes a significant contribution to fuel savings from the wind energy.

At $t=4 \mathrm{~s}$, the local load is reduced from $280 \mathrm{~kW}$ to 100 $\mathrm{kW}$; the wind speed stays the same. As a result, the wind turbine tries to supply $225 \mathrm{~kW}$, but the only load available is $100 \mathrm{~kW}$. As a result, the synchronous generator of the diesel genset turns into a motor (negative power), the governor loses its speed control, and frequency runaway is triggered. This is an example of the wind turbine being oversized compared to the local load. In such a case, a dump load (water heater, water pump, battery charger, etc.) is usually deployed to keep the diesel genset generating, which prevents it from motoring. Minimum power generation of the diesel genset is usually pre-set (for example, $15 \%-40 \%$ of the rated load). If the generated power of the diesel genset is less than the preset value, the dump load should be deployed. The dump load must be sized so that the diesel genset will always generate power above its minimum set point. The dump loads are normally non-critical loads used to store excess electrical energy in another form, such as heat (water or space heater), electric charge (battery charging), or potential energy (water pump).

\section{Oversized wind turbine with energy storage:}

As shown in the previous subsection, an oversized wind turbine can drive the system into an unstable condition because of the inability of the diesel engine to keep the frequency constant. An energy storage installed in the power system network is not only useful to remedy the undersized diesel engine but also for cases where there is an excess power produced by the wind turbine. Without energy storage, the wind turbine can drive the synchronous machine into motoring region and the frequency output will be out of

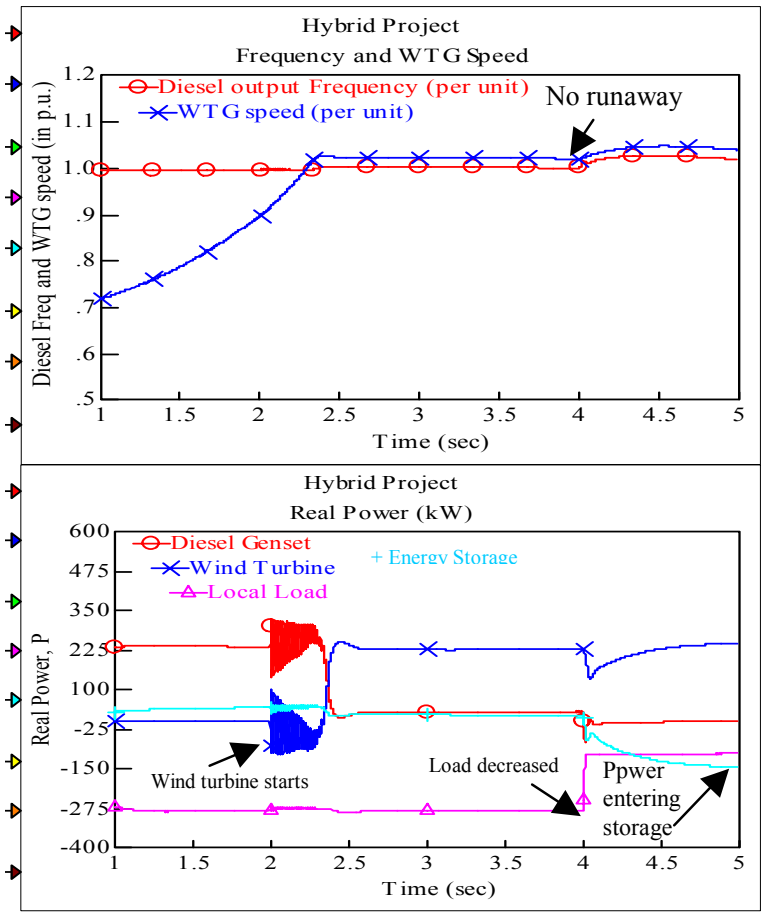

Figure 8. Voltage, rotor speed, and power of an oversize wind turbine with energy storage 
control. With a power converter to interface between the energy storage and the power network, the energy storage is capable of quickly absorbing excess power generated by the wind turbine and hold the generator rotor speed from a runaway condition. As shown in Figure 8, the frequency runaway can be prevented by using energy storage to capture the excess power in the power network.

\section{B. Case Study II: Charging the Storage Under Normal Condition}

The energy storage will be charged only when there is an energy surplus from the wind and the required network load is very light. Because the governor of the diesel generator will always maintain the frequency constant, the output power of the diesel generator is an indicator of the power within the system available to charge the energy storage. One benefit of charging the energy storage during this condition is that the efficiency of the diesel engine is at its peak when it is operated near its rated power. Thus, when a surplus of power is detected within the system, the energy storage will be charged and some energy will be stored within the system. The amount of energy and the size of charging power depend on the size of the surplus power. The charging process will be stopped when the energy storage reaches its limit. Maximum charging current is also limited by the energy storage and by the power converter interface.

Figures 9 shows the charging process. Initially there is enough wind speed to start the wind turbine. The diesel generator is supplying a constant load of $280 \mathrm{~kW}$ (power factor $=0.995$ lagging) all the time. As the wind turbine generates full power $(225 \mathrm{~kW})$, the diesel governor redistributes the load and there is a load sharing between the wind turbine and the diesel generator. As the transient settles out, it is shown that the diesel generator is contributing a very small amount of power to the load, thus the charging mechanism is started. The energy storage is charged slowly until it reaches its limit.

In Figure 9, the charging of energy storage during normal condition is limited to $75 \mathrm{~kW}$, which is about $50 \%$ of the rated power of the capacitor. This limit ensures that the power converter still has enough headroom to deliver or absorb power during an emergency. For example, if there is some loss of the loads in the power systems, the energy storage must absorb the loads loss to avoid a sudden change in frequency. Similarly, to compensate for a sudden load increase to the power systems (e.g. the water pump is

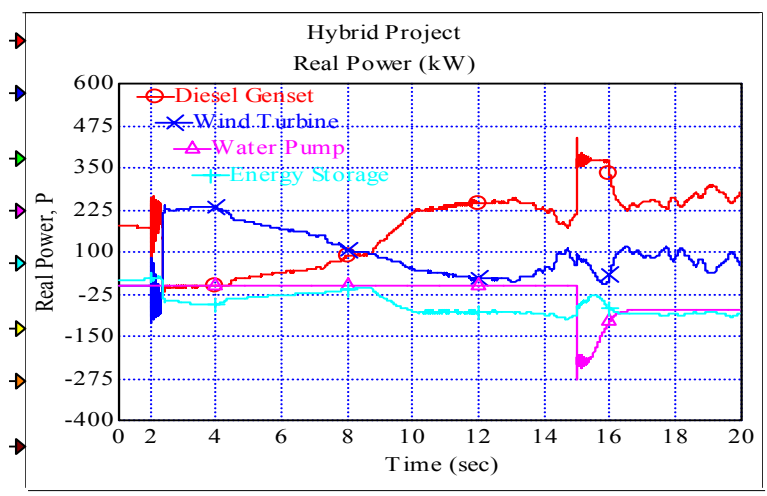

Figure 9. Real power flow in the power system started), the energy storage must release energy to the power system to keep constant frequency at the diesel generator.

As shown in Figure 9, the real power used by the energy storage to stabilize the frequency takes precedence over the charging power used to charge the storage. This can be seen especially when the water pump is started at about $t=15$ seconds.

\section{CONCLUSIONS}

After presenting an overview of the components of the power system under investigation, we described the operating characteristics of the components as they relate to voltage and frequency variations in the power network. The analysis shows the dynamic interaction among the wind turbine, diesel engine, large loads, and energy storage. It also demonstrates the dynamics of real power balance and how the system is stabilized with the controlled energy storage. The voltage regulation is very minimal and the frequency regulation is controlled very closely. The voltage regulation is controlled mostly by the balance of reactive power in the system and the time constant of the excitation system of the generator. The frequency regulation depends on the energy storage control, the size of the energy storage, the total inertia in the system (temporary energy storage).

Many technical solutions can be implemented to remedy the shortcomings covered in this paper. However, as in any power generation system, the economic implications of the solutions must be carefully considered.

\section{ACKNOWLEDGMENTS}

The first author wishes to acknowledge the strong support from NREL and the U.S. Department of Energy during this study. This project was supported under contract number DE-AC36-98GO10337.

\section{REFERENCES}

[1] E. Muljadi, L. Flowers, J. Green, and M. Bergey. 1996. "Electrical Design of Wind-Electric Water Pumping." ASME Journal of Solar Energy Engineering 118:246-252.

[2] J.T.G. Pierik and M. De Bonte. 1985. Quasi Steady State Simulation of Autonomous Wind Diesel Systems (Status Report). Report No. ECN-85-091. Petten, The Netherlands: The Netherlands Energy Research Foundation.

[3] A.J. Tsitsovits and L.L. Freris. 1983. Dynamics of an Isolated Power System Supplied from Diesel and Wind. Proc. IEEE 130, Part A, No. 9:587-595.

[4] J.T. Bialasiewicz, E. Muljadi, G. Nix, and S. Drouilhet. 1998. "RPM-SIM Simulator: A Comparison of Simulated versus Recorded Data. "Proceedings of WINDPOWER '98." Bakersfield, California, 423-432.

[5] E. Muljadi and C.P. Butterfield. 2001. "Pitch-Controlled Variable-Speed Wind Turbine Generation," Transactions of the IEEE-Industry Applications Society. 
Public reporting burden for this collection of information is estimated to average 1 hour per response, including the time for reviewing instructions, searching existing data sources,

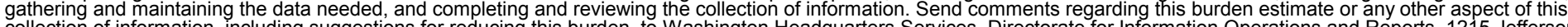

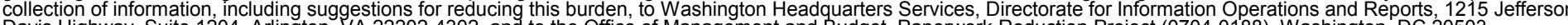
Davis Highway, Suite 1204, Arlington, VA 22202-4302, and to the Office of Management and Budget, Paperwork Reduction Project (0704-0188), Washington, DC 20503.

\begin{tabular}{|l|l|l|}
\hline 1. AGENCY USE ONLY (Leave blank) & $\begin{array}{l}\text { 2. REPORT DATE } \\
\text { November 2003 }\end{array}$ & $\begin{array}{l}\text { 3. REPORT TYPE AND DATES COVERED } \\
\text { Conference Paper }\end{array}$ \\
\hline
\end{tabular}

4. TITLE AND SUBTITLE

Hybrid Power System with a Controlled Energy Storage: Preprint

5. FUNDING NUMBERS

WER3.3520

6. AUTHOR(S)

E. Muljadi and J. T. Bialasiewicz

7. PERFORMING ORGANIZATION NAME(S) AND ADDRESS(ES)

National Renewable Energy Laboratory

1617 Cole Blvd.

Golden, CO 80401-3393

9. SPONSORING/MONITORING AGENCY NAME(S) AND ADDRESS(ES)

8. PERFORMING ORGANIZATION

REPORT NUMBER

NREL/CP-500-34692

10. SPONSORING/MONITORING AGENCY REPORT NUMBER

11. SUPPLEMENTARY NOTES

12a. DISTRIBUTION/AVAILABILITY STATEMENT

National Technical Information Service

12b. DISTRIBUTION CODE

U.S. Department of Commerce

5285 Port Royal Road

Springfield, VA 22161

13. ABSTRACT (Maximum 200 words)

We investigated a small isolated hybrid power system that used two types of power generation; wind turbine and diesel generation. The interaction of diesel generation, the wind turbine, and the local load is complicated because both the load and the wind turbine fluctuate during the day. These fluctuations create imbalances in power distribution (energy sources are not equal to energy sinks) that can affect the frequency and the voltage in the power system. The addition of energy storage will help balance the distribution of power in the power network. For this paper, we studied the interaction among hybrid power system components and the relative size of the components. We also show how the contribution of wind energy affects the entire power system and distribution and the role of energy storage under the transient conditions caused by load changes and wind turbine start ups.

\begin{tabular}{|c|c|c|c|c|}
\hline \multirow{2}{*}{\multicolumn{4}{|c|}{$\begin{array}{l}\text { 14. SUBJECT TERMS } \\
\text { wind turbine; diesel generator; hybrid power system; renewable energy; energy storage }\end{array}$}} & \multirow{2}{*}{$\begin{array}{l}\text { 15. NUMBER OF PAGES } \\
\text { 16. PRICE CODE }\end{array}$} \\
\hline & & & & \\
\hline 17. & $\begin{array}{l}\text { SECURITY CLASSIFICATION } \\
\text { OF REPORT } \\
\text { Unclassified }\end{array}$ & $\begin{array}{l}\text { 18. SECURITY CLASSIFICATION } \\
\text { OF THIS PAGE } \\
\text { Unclassified }\end{array}$ & $\begin{array}{l}\text { 19. SECURITY CLASSIFICATION } \\
\text { OF ABSTRACT } \\
\text { Unclassified }\end{array}$ & $\begin{array}{l}\text { 20. LIMITATION OF ABSTRACT } \\
\text { UL }\end{array}$ \\
\hline
\end{tabular}

